\title{
Evidence for recovery of a surf-zone fish assemblage following the establishment of a marine reserve on the southern coast of South Africa
}

\author{
B. A. Bennett, C. G. Attwood \\ Zoology Department and Marine Biology Research Institute, University of Cape Town, Rondebosch 7700, South Africa
}

\begin{abstract}
This study was designed to establish whether populations of fish species important in the catches of rock and surf anglers increased following the proclamation of the De Hoop Marine Reserve on the southern coast of South Africa. Catch per unit effort (CPUE) and size frequency distributions of angling species were monitored approximately monthly by angling from the shore at 2 sites in the reserve. At one site sampling commenced 2 yr before the reserve was established and continued $4.5 \mathrm{yr}$ thereafter, allowing comparisons of periods of exploitation and protection. The other site had a long history of minimal exploitation and data collected there 2.5 to $4.5 \mathrm{yr}$ after complete protection was considered to represent an unexploited condition. Ten species accounted for $99 \%$ of the catch. Following establishment of the reserve, CPUE increased for 6 of these (galjoen Coracinus capensis, dassie Diplodus sargus, wildeperd $D$. cervinus, white steenbras Lithognathus lithognathus, Cape stumpnose Rhabdosargus holubi and musselcracker Sparodon durbanensis). The catch rates of 2 species (C. capensis and D. sargus) improved 4 to 5 fold within 2 yr of protection and remained at these high levels, which were similar to the unexploited catch rates. Recoveries were slower amongst the other 4 species, their catch rates reaching 30 to $60 \%$ of the unexploited level after 2.5 to 4.5 yr of protection. This study provides evidence of general stock recoveries of exploited fish species in a shallow marine habitat following protection within a marine reserve.
\end{abstract}

\section{INTRODUCTION}

Angling from the seashore is a popular pursuit among a large and ever-increasing number of South Africans. It provides recreation and a cheap source of protein for a wide spectrum of the population and is a major source of income for the coastal tourism and fishing tackle industries. There is strong evidence, however, that this form of exploitation is having detrimental effects on the stocks of many of the target species (van der Elst 1989, Bennett 1990) and a comprehensive set of restrictions has been imposed on this fishery in recent years. These restrictions include the declaration of portions of the coast as marine reserves. The declared objective of these marine reserves was to protect depleted stocks in the hope that they would recover fully and attain levels that would result in restocking of adjacent areas. Marine reserves are, however, a relatively new phenomenon and their effective- ness, at least for fish stocks, has not yet been adequately demonstrated. The first statutory marine reserves in New Zealand and Britain, for example, were only established in 1977 and 1986 respectively (Ballantine 1987, Kayes 1987) and, until recently, they were considered to be 'radically new experiments' (Ballantine 1987). In December 1985, when the De Hoop Marine Reserve was proclaimed, only a few attempts at assessing the effect of fishing restrictions on fish communities in reserves had been attempted (Bell 1983, Russ \& Alcala 1989) and their likely effectiveness was unknown.

The typical symptoms of excessive fishing pressure on fish populations are decreases in mean size and density of target species (Nikolsky 1969, Weatherley 1972). Visual censusing of the fish populations in marine reserves and nearby unexploited sites has been undertaken in temperate (Bell 1983, Buxton \& Smale 1989, Cole et al. 1990) and tropical reef areas (Alcala 
1988, Russ \& Alcala 1989). All these studies showed that modal sizes and densities of some species normally caught by fishermen were greater in the reserves. However, increased modal sizes and densities were not confined to exploited species: higher values were also noted among species seldom caught by fishermen. Conversely, in some cases high densities of target species were noted in exploited areas adjacent to reserves. Findings such as these indicate that differences in fish community structure cannot be attributed entirely to protection. Indeed, in all the studies cited above, the authors concede that the reefs in their reserve and 'control' sites (where exploitation took place) were not identical. Comparing an existing reserve with an exploited area might confirm that the unfished community differs from the exploited one, but it is not in itself evidence that an exploited community will recover to its pristine state should exploitation be halted. Recovery may be prevented by the establishment of an alternative stable community, or be retarded by a low resilience of the system (Pimm 1984). Inherent differences between localities may also result in different fish communities, so that protection per se need not necessarily lead to the establishment of dense, diverse fish populations.

Alcala (1988) and Russ \& Alcala (1989) documented a decrease in density of target species following the exploitation of a previously protected reef, and Koslow et al. (1988) analysed changes in catch rates and species composition after fishing effort increased. These studies also showed that changes in the fish community, or in catches, frequently reflected changes in the populations of non-targetted as well as targetted species. This highlights the concern that population recoveries may not be a simple matter of allowing sufficient time to pass, but may be delayed or prevented by complicating factors such as changes in habitat or long-term alterations of predator-prey relationships or competitive interactions.

More direct attempts at demonstrating recoveries in fish populations following protection were made by Russ \& Alcala (1989) and Cole et al. (1990). Cole et al. (1990) attempted to establish whether temporal changes in fish abundance had occurred after creation of a marine reserve on the New Zealand coast. They were unable to detect consistent differences between surveys undertaken 3 and $13 \mathrm{yr}$, or at approximately yearly intervals between 1 and 7 yr after protection. This lack of conclusive results was thought to be a consequence of factors such as emigration from the study area, patchy distributions, difficulty with the censusing technique and a lack of base-line information. prior to and immediately after the declaration of the reserve. The results obtained from the 1983 and 1985 censuses in the Apo Reserve, Phillipines, by Russ \&
Alcala (1989) also failed to provide evidence that fish populations increase following protection. In this case, it was considered by Alcala (1988) that insufficient time had elapsed for the effects of protection to be evident.

Many reasons as to why it has been difficult to obtain unequivocal evidence demonstrating that protection leads to increases in fish populations have already been advanced. The most important of these is probably inadequacy of experimental design. A feature common to all the above studies is that the fish communities were not studied before the areas were closed to exploitation. In no cases, therefore, were the authors able to prove convincingly that the fish community in a particular site had been enhanced following protection.

This paper presents the results of a long-term CPUE and size-frequency monitoring exercise that commenced 2 yr prior to the proclamation of the De Hoop Marine Reserve and continued for 4.5 yr thereafter. Data collected throughout this period at one site (Koppie Alleen) were used to examine the effectiveness of the marine reserve in promoting the recovery of fish stocks previously exploited by shore-based anglers. Assessments of the rates and magnitudes of recoveries were made by comparing changes in CPUE over time with CPUE from a nearby site (Lekkerwater), where exploitation was historically minimal.

\section{MATERIALS AND METHODS}

Study sites. The De Hoop Nature Reserve (Fig. 1) is situated ca $60 \mathrm{~km}$ east of Cape Agulhas on the southern coast of South Africa. The protected area of coastline is $46 \mathrm{~km}$ long, and lies WSW to ENE so as to be exposed to prevailing oceanic swells from the southwest.

The 2 study sites, Koppie Alleen and Lekkerwater, are situated ca $15 \mathrm{~km}$ apart and each is ca $15 \mathrm{~km}$ from the nearest border of the reserve. At both sites the shore is a mixture of sandy beach and aeolianite beachrock platforms of recent geological origin. Erosion of these platforms has caused the sandy sea bed to be interspersed with patches of rock of varying size and complexity These patches of rock occur almost exclusively at a depth of less than $6 \mathrm{~m}$, and are thus all within the surf-zone which usually extends 150 to $300 \mathrm{~m}$ from the shore. The high wave exposure and complex sea bed cause the sand to be extremely mobile. It is frequently eroded and deposited, uncovering and covering patches of rock on spatial scales of metres to hundreds of metres and temporal scales of hours to years. This sediment mobility has important consequences for fish since it maintains the invertebrate and algal communities on the rocks in early successional stages at which they are most available for consumption.

The 2 study sites had markedly different histories of 
Fig. 1. Location of study area on the southern African coast and map of the De Hoop Reserve showing the position of the sampling sites

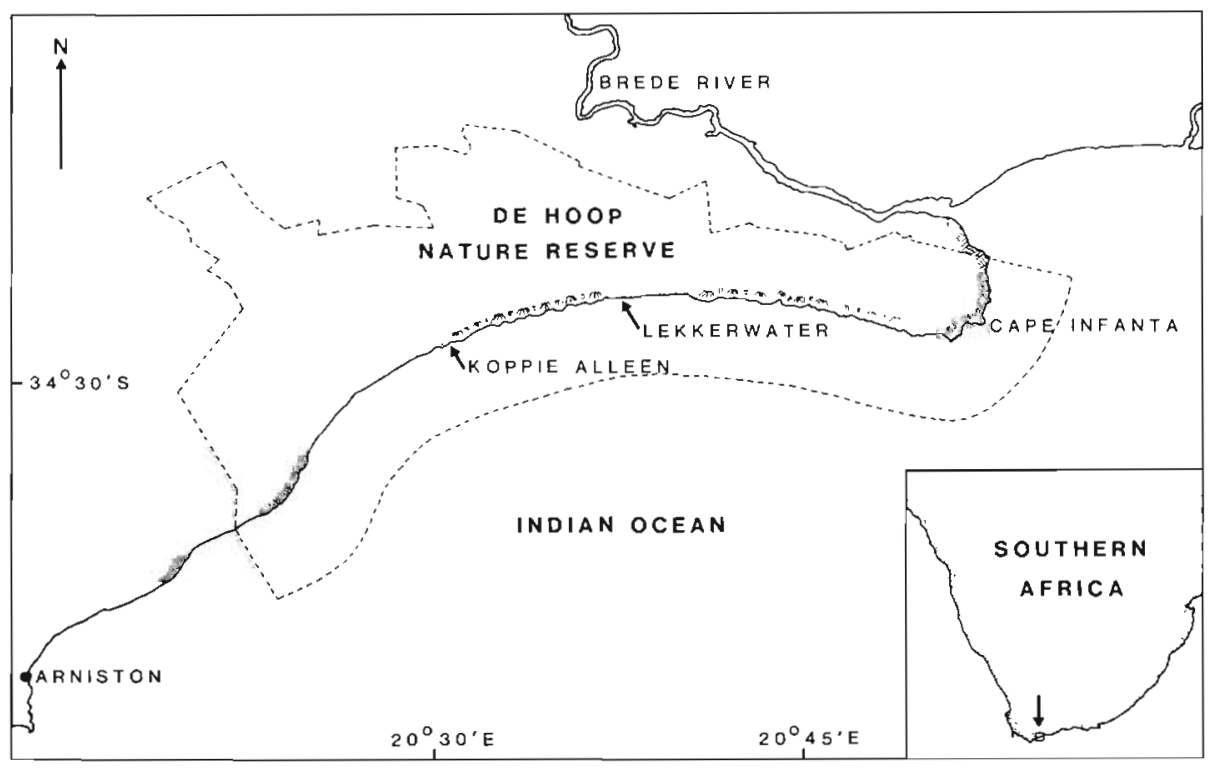

exploitation. Before 1986 fishing was allowed at Koppie Alleen and the area was easily accessible through state land. Lekkerwater was privately owned and access was denied to all but the owner and his immediate family, who all lived at least $250 \mathrm{~km}$ away and used the area only for holidays. Observations of angling effort at Koppie Alleen were made on 17 weekdays and 20 weekend-days, usually over 4 consecutive days at ca 2 mo intervals, during the 2 yr prior to its closure to angling. This revealed that an average of 8.65 ( $\mathrm{SD}=$ 7.43 , range $=0$ to 24$)$ and $21.00(\mathrm{SD}=6.81$, range $=7$ to 29) anglers were present on weekdays, and on weekends and public holidays, respectively. Interviews with 64 anglers indicated that they spent an average of $6.83 \mathrm{~h}(\mathrm{SD}=2.01$, range $=1.5$ to 11.0$)$ fishing each day. Given an average of 251 weekdays and 114 weekend and holidays in a year, total annual angling effort at Koppie Alleen prior to its closure was 31179 anglerhours

An interview with the former owner of Lekkerwater indicated that there were people present at this site for a maximum of $72 \mathrm{~d}$ per year with an estimated 2.5 fishermen present at any time. It was further estimated that these fishermen seldom fished for more than $5 \mathrm{~h}$ per day. This is equivalent to a maximum annual fishing effort of $900 \mathrm{~h}$. Fishing effort at Lekkerwater was thus less than $3 \%$ of that at Koppie Alleen.

Methods. Samples were collected by a group of 4 to 6 anglers over 4 to $5 \mathrm{~d}$ at 4 to $8 \mathrm{wk}$ intervals on 53 separate occasions between May 1984 and August 1990. The data from Koppie Alleen were separated into 3 phases: P1, May 1984 to September 1985, the period prior to closure; P2, October 1985 to February 1988, the 29 mo immediately after closure; and P3, April 1988 to August 1990, the remaining 29 mo of the sampling period. The Lekkerwater data were collected concurrently with the third Koppie Alleen period (P3). During the period that both sites were being sampled they were visited on alternate months.

The composition of the angling party was kept as constant as possible in order to reduce the effects of differing skills, and fishing methods were standardised. The rods (fibreglass or carbon fibre, 3.5 to $4.5 \mathrm{~m}$ long), reels (revolving-spool multipliers), line (monofilament 0.5 to $0.6 \mathrm{~mm}$ diameter), hooks (Mustad \# 1 to $2 / 0$ ), bait (redbait Pyura spp., white mussel Donax serra and polychaete worms) and other aspects of the tackle were the same on all sampling occasions. The species and length of each fish caught by each angler on each day was recorded, as was the number of hours spent fishing. During the time that the area was open to the angling public all fish of 'edible size' were retained; after the declaration of the reserve all fish were released, those that were large enough (usually $>25$ to $35 \mathrm{~cm}$, depending on species) bearing tags.

Fish abundances before and after closure at Koppie Alleen and at Lekkerwater were estimated from catch frequencies (fish $\mathrm{d}^{-1}$ ) normalised by daily effort ( $\mathrm{h} \mathrm{d}^{-1}$ ). The resulting catch per unit effort (CPUE) was expressed as fish caught per 100 angler-hours.

The rationale used in this study is that abundance $(N)$ is directly related to CPUE. Gulland (1983) noted that the catchability factor, $q$, in the relation CPUE $=$ $\mathrm{Nq}$, while normally assumed to be constant, often varies according to a number of parameters. Three of these are pertinent to this study, viz. changes with respect to abundance, to fishing gear and cyclical environmental changes. Although for purse-seine fisheries there is a valid argument for $q$ being inversly related to $N$ (Gulland 1983), we assumed that for shore-angling each 
Table 1. Numbers of the 10 important target species sampled in the De Hoop Reserve and details of the total catch, total number of species and effort. P1 is the period prior to closure at Koppie Alleen, P2 is the 29 mo period immediately after closure, P3 the following 29 mo period. LW data were obtained at nearby Lekkerwater during P3

\begin{tabular}{|c|c|c|c|c|c|}
\hline & \multicolumn{3}{|c|}{ Koppie Alleen } & \multirow[t]{2}{*}{ LW } & \multirow[t]{2}{*}{ Total } \\
\hline & P1 & P2 & P3 & & \\
\hline \multicolumn{6}{|l|}{ Coracinidae } \\
\hline Galjoen Coracinus capensis & 307 & 1544 & 2029 & 3834 & 7714 \\
\hline \multicolumn{6}{|l|}{ Pomatomidae } \\
\hline Elf Pomatomus saltatrix & 10 & 3 & 2 & 7 & 22 \\
\hline \multicolumn{6}{|l|}{ Scianidae } \\
\hline Kob Argyrosomus hololepidotus & 33 & 15 & 23 & 6 & 77 \\
\hline Belman Umbrina canariensis & 41 & 31 & 52 & 23 & 147 \\
\hline \multicolumn{6}{|l|}{ Sparidae } \\
\hline Wildeperd Diplodus cervinus hottentottus & 12 & 21 & 49 & 149 & 231 \\
\hline Dassie Diplodus sargus capensis & 256 & 848 & 1169 & 2131 & 4404 \\
\hline Bronze bream Pachymetopon grande & 1 & 0 & 0 & 32 & 33 \\
\hline Cape stumpnose Rhabdosargus holubi & 6 & 22 & 28 & 117 & 173 \\
\hline White steenbras Lithognathus lithognathus & 6 & 18 & 50 & 273 & 347 \\
\hline Musselcracker Sparodon durbanensis & 0 & 4 & 9 & 27 & 40 \\
\hline Other species & 38 & 35 & 49 & 62 & 184 \\
\hline Total catch $(\mathrm{N})$ & 710 & 2541 & 3460 & 6661 & 13372 \\
\hline Total no. of species & 18 & 21 & 22 & 26 & 29 \\
\hline Total effort (angler-hours) & 1421 & 1423 & 1900 & 3188 & 7932 \\
\hline No. of trips & 11 & 14 & 15 & 13 & 53 \\
\hline
\end{tabular}

fish had an equal catchability, irrespective of abundance. Fishing gear and the skill of anglers were kept as constant as possible and the grouping of the Koppie Alleen samples into 3 periods was designed to ensure that each period covered sufficient time to reduce the effect of environmental variability.

Ten of the 29 species sampled were chosen for detailed analysis (Table 1 ). These teleost species provided the bulk of the catch of anglers in the southwestern Cape (Bennett 1990, unpubl.). The remaining species were either cartilaginous, attained only small sizes or were rarely caught.

The 53 samples from Koppie Alleen and Lekkerwater were classified hierarchically to show relationships between them as described by Gauch (1982). Dissimilarities between samples were calculated from the CPUE data for each of the 29 species using the BrayCurtis similarity index. Samples were clustered in a dendrogram by the group average sorting procedure, which joins 2 groups of samples at their average level of similarity (Field et al. 1982).

Variances in the catch rates of each of the 10 species across the 3 Koppie Alleen sampling periods and at Lekkerwater were examined for homogeneity using Bartlett's test. Where variances could be assumed to be homogeneous (i.e. $p>0.05$ ), differences in catch rates between sampling periods were sought using 1 -way ANOVA $(p<0.05)$. Tukey's multiple comparison procedure was then used to establish between which sampling periods the mean catch rates of each species were different. Where variances were not homogeneous the non-parametric Kruskal-Wallis test was used to compare catch rates.

\section{RESULTS}

A total of 7932 angler hours of effort was expended and 13372 fish of 29 species caught (Table 1). Coracinus capensis and Diplodus sargus were numerically dominant in all samples, providing $57.7 \%$ and $32.9 \%$ of the total catch respectively. Together with the 8 other species listed in Table 1 they provided ca $99 \%$ of the total number of fish sampled in the reserve. A summary of total effort and total catch of the 10 numerically most important species is given in Table 1.

Cluster analysis of the untransformed CPUE data of all species (including the non-target species) in all samples indicated that the samples from Koppie Alleen during P1 form a group discrete from all the other samples (Fig. 2). The remaining samples all group above the $60 \%$ similarity level and do not show any clear site- or period-related groupings. The difference between the 2 major groups is explained by the considerably lower catch rates of the 2 most abundant species (Coracinus capensis and Diplodus sargus) at Koppie Alleen during P1. To reduce the dominating effects of the abundant species further classification analyses 


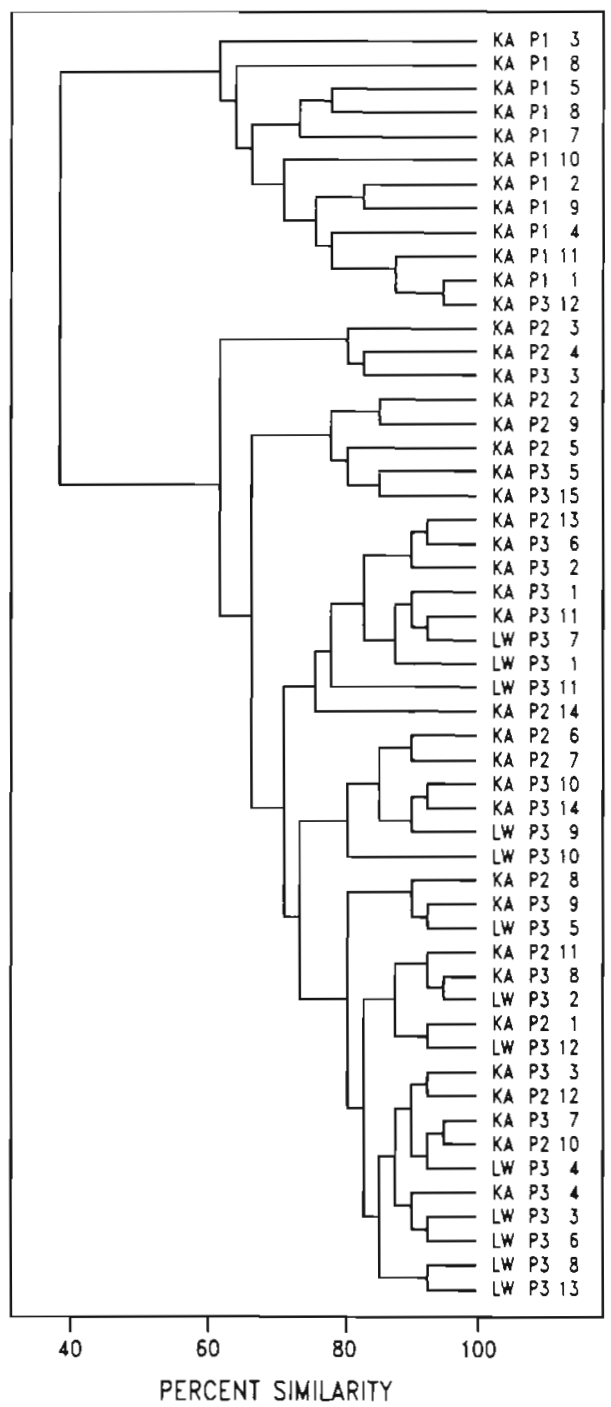

Fig. 2. Dendrogram resulting from group average Bray-Curtis similarity of untransformed catch rates, showing the relationships between individual samples according to catch composition. KA and $\mathrm{LW}$ refer to the 2 sampling localities, Koppie Alleen and Lekkerwater; P1 is the period prior to closure, P2 is the 29 mo period immediately after closure, P3 the following 29 mo period. Samples from each site during each period are numbered chronologically

were conducted in which CPUE was root-root transformed and in which varying numbers of the non-target species were omitted. Only indistinct groupings were evident in the resulting dendrograms, e.g. samples from P1 at Koppie Alleen and from Lekkerwater tended to form separate groups but, in nearly all cases, all the samples grouped above the $75 \%$ level. This marked degree of similarity between all samples suggests that there were no substantial differences in the species composition and the (root-root transformed) relative abundance throughout the sampling period, or between the 2 areas.
Despite the lack of clear-cut differences between the different sampling periods at the 'community' level the catch rates of several species differed quite markedly between sites and over time (Fig. 3). The catch rates of 6 of the species (Coracinus capensis, Diplodus sargus,
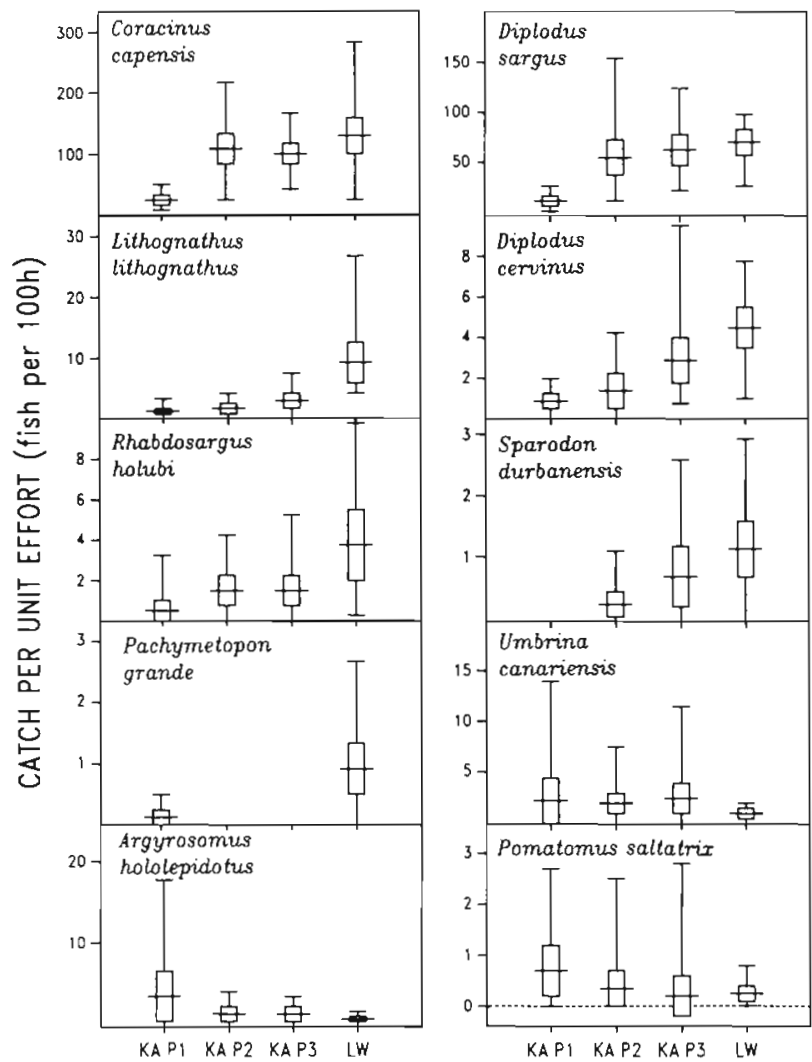

Fig. 3. 'Box and whisker' plots of the catch rates of the 10 numerically most important target species in the De Hoop Reserve. Horizontal lines represent the mean, boxes the standard deviation and vertical lines the range of CPUE for each species during each of the 3 sampling periods (P1 to P3) at Koppie Alleen (KA) and Lekkerwater (LW)

D. cervinus, Lithognathus lithognathus, Rhabdosargus holubi and Sparodon durbanensis) increased after closure of the coast at Koppie Alleen to exploitation (ANOVA, p < 0.05) (Table 2). The highest catch rates of all these species were recorded at Lekkerwater. Catch rates of the other 4 species at Koppie Alleen either showed no clear pattern or decreased after closure of the area.

The results of Tukey's tests, which were used to determine significant differences between the groups of samples, are summarised in Fig. 4. Coracinus capensis and Diplodus sargus exhibited similar patterns, with their mean catch rates at Koppie Alleen while it was open to exploitation (P1) being significantly different from the subsequent 2 periods and from Lekkerwater. The catch rates of these 2 species during $\mathrm{P} 1$ at Koppie 
Table 2. Results of 1-way ANOVAS of log-transformed catch rates of the 10 most frequently caught species between the 3 sampling periods at Koppie Alleen and one at Lekkerwater. Bartlett's $P$ is the probability that the samples are not heteroscedastic. $\cdots p<0.001, \cdots p<0.01$, ns: not significant; - indicates that the test was not performed as samples were heteroscedastic (see Table 3)

\begin{tabular}{|c|c|c|c|}
\hline & Bartlett's $P$ & F-ratio & Significance level \\
\hline Coracinus capensis & 0.30 & 33.39 & $\cdots$ \\
\hline Diplodus sargus & 0.69 & 20.85 & $\cdots$ \\
\hline Lithognathus lithognathus & 0.18 & 25.40 & $\cdots$ \\
\hline Diplodus cervinus & 0.31 & 11.63 & $\cdots$ \\
\hline Rhabdosargus holubi & 0.55 & 5.04 & $\cdots$ \\
\hline Sparodon durbanensis & 0.13 & 7.22 & $\cdots$ \\
\hline Pachymetopon grande & $1.01 \times 10^{-3}$ & - & - \\
\hline Umbrina canariensis & 0.11 & 1.84 & ns \\
\hline Argyrosomus hololepidotus & $1.56 \times 10^{-5}$ & - & - \\
\hline Pomatomus saltatrix & 0.05 & - & - \\
\hline
\end{tabular}
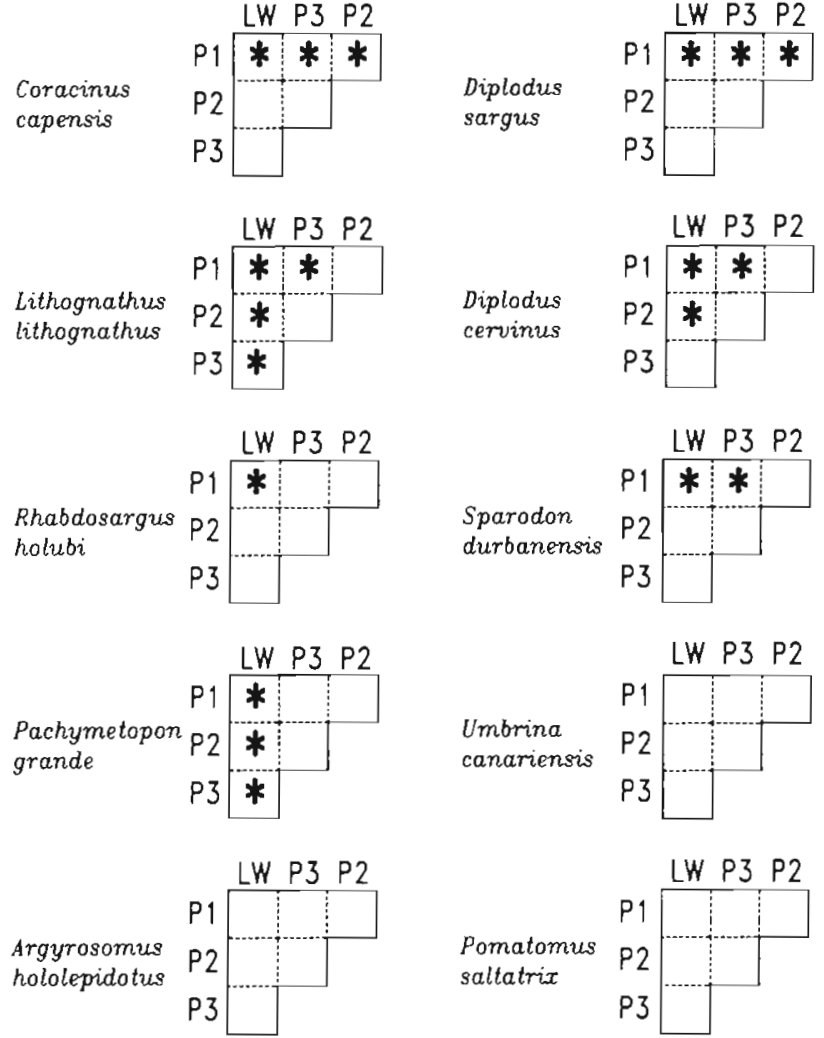

Fig. 4. Pictorial representation of the results of Tukey's tests on CPUE data for each of the 10 target species in the 4 samples - Denotes significant difference $(p<0.05)$ between 2 samples

Alleen were ca $20 \%$ of the 'unexploited' Lekkerwater level but they increased rapidly to $90 \%$ of this level shortly after protection (P2) and remained high. Mean CPUE for Lithognathus lithognathus, Diplodus cervinus, Sparodon durbanensis and Rhabdosargus holubi recovered more gradually (Fig. 3). For all these species catch rates during P1 at Koppie Alleen differed significantly from the Lekkerwater rates, but there were often no differences between adjacent sampling periods (Fig. 4). Catch rates of these species increased gradually from between 0 and $15 \%$ of the Lekkerwater rate to between 30 and $60 \%$ of this rate some 3 yr later. Pachymetopon grande, the other species for which a significant difference in CPUE was indicated, did not conform to the 2 patterns outlined above. Only one individual of this species was ever caught at Koppie Alleen and 32 at Lekkerwater. No differences in catch rates across the sampling periods existed for Umbrina canariensis, Argyrosomus hololepidotus and pomatomus saltatrix. (Table 3).

For 8 of the 10 species studied there were no clear patterns of increasing size across the 3 sampling periods, or between the 2 sites, that might be attributable to the benefits of protection. The size distributions of most species were characterised by small sample sizes, differing cohort strengths and, in many cases, there was substantial overlap in size ranges across the 4 samples. Interpretation was further complicated by a lack of information on the growth and migration rates of many of the species. Exceptions to this were Coracinus capensis and Diplodus sargus. The mean and modal sizes of $D$. sargus increased from $\mathrm{P} 1$ through P2 to P3 and were largest at Lekkerwater (Fig. 5). The data for C. capensis were less straightforward (Fig. 6). The size distribution of this species at Koppie Alleen during P1 was clearly bimodal, whereas during P2 it was strongly skewed to the right. During P3 at both Koppie Alleen and Lekkerwater it was skewed to the left. This somewhat confusing picture is probably explicable in terms of differing year class strengths and the transient presence of a cohort of large fish at Koppie Alleen during $\mathrm{P} 1$ and $\mathrm{P} 2$. 
Table 3. Results of non-parametric Kruskall-Wallis test on the untransformed catch rates of the 4 species which could not be tested parametrically. $\cdots p<0.001$, ns: not significant. KA P1, KA P2, KA P3 and LW represent the 3 Koppie Alleen sampling periods and Lekkerwater respectively

\begin{tabular}{|c|c|c|c|c|c|c|}
\hline \multirow[t]{3}{*}{ Species } & \multicolumn{4}{|c|}{ Average rank } & \multirow[t]{3}{*}{$H$-statistic } & \multirow{3}{*}{$\begin{array}{c}\text { Significance } \\
\text { level }\end{array}$} \\
\hline & KA P1 & KA P2 & KA P3 & LW & & \\
\hline & $\mathrm{n}=11$ & $\mathrm{n}=14$ & $n=15$ & $\mathrm{n}=13$ & & \\
\hline Umbrina canariensis & 28.52 & 27.43 & 31.83 & 19.26 & 4.73 & ns \\
\hline Argyrosomus hololepidotus & 29.63 & 29.14 & 28.30 & 20.96 & 3.04 & ns \\
\hline Pachymetopon grande & 23.41 & 21.00 & 21.00 & 43.42 & 36.63 & $\cdots$ \\
\hline Pomatomus saltatrix & 31.45 & 25.00 & 24.67 & 28.08 & 2.90 & $\mathrm{~ns}$ \\
\hline
\end{tabular}

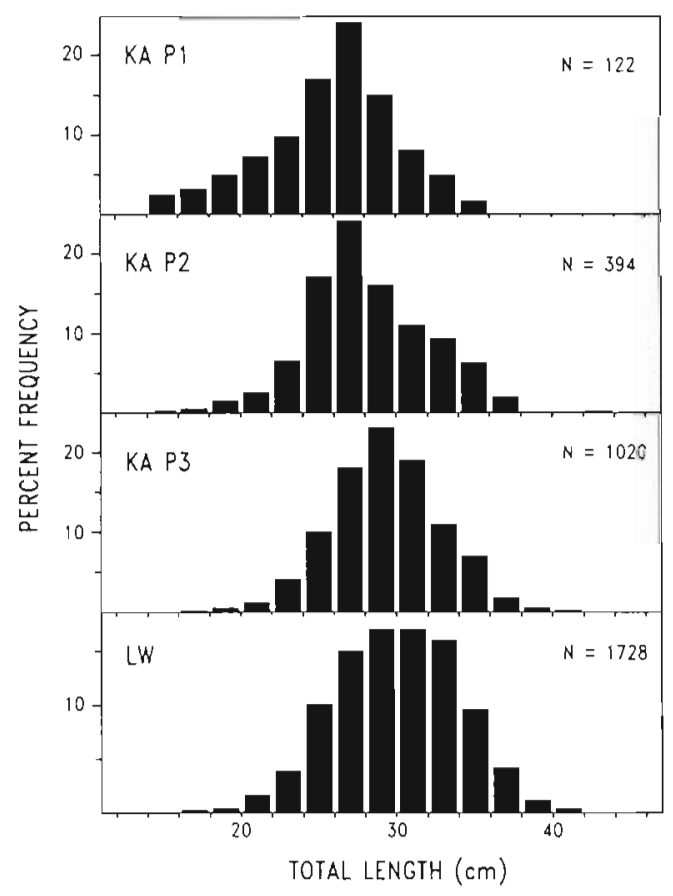

Fig. 5. Size frequency distributions of dassie Diplodus sargus during each of the 4 sample periods

\section{DISCUSSION}

The present study provides the first good evidence that the populations of most target species increased following the declaration of the marine reserve at De Hoop. The 6 species for which CPUE improved are the most important angling species which together accounted for almost $97 \%$ of the total catch.

Efforts were made to ensure that the relationship between CPUE and abundance was constant throughout the sampling periods. One factor that could not be accounted for when assessing changes in CPUE after protection was the effect that the presence of other

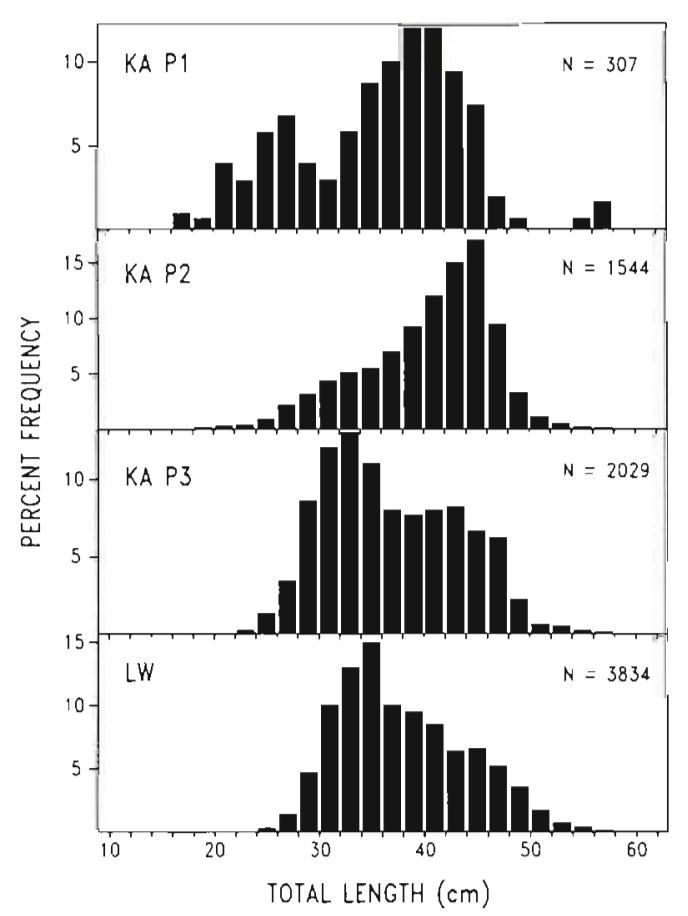

Fig. 6. Size frequency distributions of galjoen Coracinus capensis during each of the 4 sample periods

anglers may have had on the research catches at Koppie Alleen during P1, when the coast was open to the angling public. It is probable that 2 of the 3 types of 'gear competition' described by Ricker (1975) were in operation: (1) a local depletion of the fish supply occurred; (2) physical interference between the research group and the public in terms of the occupation of prime 'spots' and the disturbance of actively-feeding shoals took place. These factors would have tended to result in reduced CPUE during $\mathrm{P} 1$ relative to subsequent periods, with this reduction not necessarily being attributable to a smaller fish population. However, a third type of competition described by Ricker (1975) 
would have tended to have the opposite effect. This type of competition operates on a broader scale and involves the catch and effort over the entire range of the species in question. Here the local units of effort do not interfere directly with each other; rather, competition is a result of a reduction in the size of the population as a whole. Reductions in the populations of angling species around the South African coast are occurring as a result of exponentially increasing effort (van der Elst 1989, Bennett 1990). This means that fewer fish would have been available to disperse into the reserve as time progressed and, given that population recoveries were taking place in the reserve as a result of protection, the fish density gradient between the reserve and adjacent exploited areas is likely to have steepened during the course of the study. For these reasons it is possible that movement between the reserve and adjacent areas was accelerated, resulting in an increased dispersal of fish out of the reserve over time. This effect would have resulted in CPUE being relatively higher during early samples than later ones.

A further factor likely to have affected the comparability of the results is competition between species for the gear. Catches of a particular species would decrease as it became relatively, rather than absolutely, less abundant in the assemblage as a whole (Gulland 1964, Rothschild 1967), thus depressing the catch rates of rarer species.

The relative magnitudes of the biases caused by each of the factors are unknown. It is likely, however, that each affects the 'before' and 'after' CPUE data to a different extent and that the effects differ between species. Factors that would depress catch rates after closure of the coast to the public do not adversely affect interpretation of the results concerning population recoveries since significant increases were found despite these possible effects. Their only effect would have been to cause an underestimation of recovery rates.

Only the first 2 types of 'competition' outlined above (i.e. those which would have caused CPUE during P1 to be lower relative to the subsequent periods) are likely to negate the findings of this paper if they were substantial. Fig. 3 indicates that this may indeed be the case for Coracinus capensis and Diplodus sargus (but not for the ather species). Both these species showed increases in CPUE following protection that were greater, and occurred more rapidly, than might have been expected from population recoveries. The 4- to 5-fold increase in mean CPUE of $C$. capensis that occurred within a few months of protection may well have been a result of the removal of interference by the angling public. The length-frequency data for this species (Fig. 6) indicate a strong mode at $40 \mathrm{~cm}$ during P1 which corresponds to an age of ca 7.5 yr (Bennett \&
Griffiths 1986). The modal size during P2, some 2 yr later, was $45 \mathrm{~cm}$ or $9.5 \mathrm{yr}$, thus indicating the passage of a strong cohort through the population. When this cohort of large individuals disappeared at the end of P2, catch rates did not decrease significantly, indicating that an increase in population size had occurred through recruitment.

The size distribution of Diplodus sargus did not change appreciably between P1 and P2 (Fig. 5). In this case the rapid increase in catch rates may be explained by interference competition, but the gradual increase in mean CPUE and modal size thereafter suggests a progressive recovery of the population. The increase from 27 to $29 \mathrm{~cm}$ between P2 and P3 is equivalent to ca 2 yr of growth (B. Mann, Rhodes University, pers. comm.) and is therefore an expected result of effective protection. The above discussion of size frequency distributions presupposes a high degree of residency for Coracinus capensis and $D$. sargus. This assumption is reasonable since tagging studies have shown C. capensis to be resident in small areas $(<3 \mathrm{~km}$ of shore) for long periods (Bennett et al. 1989) with less than $10 \%$ of the population 'diffusing' out of $50 \mathrm{~km}$ length of shore annually. The data on $D$. sargus are not as comprehensive, but of ca 1900 individuals tagged in the De Hoop Nature Reserve, 48 have been recaptured, none more than $3 \mathrm{~km}$ from their point of release (Bennett unpubl.). Only 2 of the 10 species examined in this study, Argyrosomus hololepidotus and Pomatomus saltatrix, are highly migratory (van der Elst 1981) and neither demonstrated any benefits from protection in the reserve. The other species which did not appear to benefit, Umbrina canariensis, may also be migratory since the catches of this species in the southwestern Cape form a very marked peak during late summer (unpubl. data, Sea Fisheries Research Institute, Cape Town). Their absence from catches in this area during the remainder of the year suggests that they may have migrated elsewhere. Little is known of the migratory habits of the remaining species, all of which appeared to benefit from protection. These species were, however, caught in varying numbers throughout the year in the reserve and none of the individuals tagged there were caught elsewhere. The fact that recoveries were evident in the De Hoop populations suggests that individuals are largely confined to areas of coastline less than $50 \mathrm{~km}$ long.

It is evident that angling CPUE should be interpreted with some caution. It appears reasonable, however, to accept that the trends indicated by the data are real and that the biases are not sufficiently large to cause the interpretation of increased catch rates as being due to sampling artefacts, rather than to fish population recoveries. Angling CPUE was the most practical way to assess stock recoveries in the De Hoop Reserve given 
the foul nature of the substratum and the high degree of wave exposure. Other sampling techniques such as seine and gill nets, traps, SCUBA observation, or even poisons and explosives all have their own biases and could not have been used in the pounding surf adjacent to a rocky shore.

Despite some possible uncertainties in the interpretation of the data, this study provides strong evidence for population recoveries by a number of fish species. Catch per unit effort data indicated that the population sizes of 6 important angling species (which together provided $97 \%$ of the total catch) improved following protection. Thus the protection offered by the De Hoop Marine Reserve allowed the recovery of previously exploited fish populations.

Acknowledgements. We thank all those anglers who gave so freely of their time (especially L. Hutchings, M. Johnson, S. Walker and W de Wet), and the Cape Department of Nature and Environmental Conservation, who provided accommodation and logistic support. This work was financed by the Sea Fisheries Research Fund, the South African Committee for Oceanographic Research and the Foundation for Research Development. C. L. Griffiths, G. M. Branch, L. Hutchings and P. A. R. Hockey all provided comments which improved the manuscript.

\section{LITERATURE CITED}

Alcala, A. C. (1988). Effects of marine reserves on coral fish abundances and yields of Phillipine coral reefs. Ambio 17 194-199

Ballantine, W. J. (1987). New Zealand's course for marine reserves. New Scientist 114: 54-55

Bell, J. D. (1983). Effects of depth and marine reserve fishing restrictions on the structure of a rocky reef fish assemblage in the northwestern Mediterranean Sea. J. appl. Ecol. 20 $357-369$

Bennett, B. A. (1990). Long-term trends in the catches by shore anglers in False Bay. Trans. R. Soc. S. Afr. 47: 683-690

Bennett, B. A., Attwood, C. G., Griffiths, C. L. (1989). Focus on galjoen - preliminary tagging results. Tagging News 5 8-9

This article was submitted to the editor
Bennett, B. A., Griffiths, C. L. (1986). Aspects of the biology of the galjoen Coracinus capensis (Cuvier) off the southwestern Cape, South Africa. S. Afr. J. mar. Sci. 4: 153-162

Buxton, C. D., Smale, M. J. (1989). Abundance and distribution patterns of three temperate marine fish (Teleostei: Sparidae) in exploited and unexploited areas off the southern Cape coast. J. appl. Ecol. 26: 441-451

Cole, R. G., Ayling, A. M., Creese, R. G. (1990). Effects of marine reserve protection at Goat Island, northern New Zealand. N.Z. J. mar. Freshwater Res. 24: 197-210

Field, J. G., Clarke, K. R., Warwick, R. M. (1982). A practical strategy for analysing multi-species distribution patterns. Mar. Ecol. Prog. Ser. 8: 37-52

Gauch, H. G. (1982). Multivariate analysis in community ecology. Cambridge University Press, Cambridge

Gulland, J. A. (1964). Manual for methods of fish population analysis. FAO Fish. Tech. Pap. 40: 1-60

Gulland, J. A. (1963). Fish stock assessment: a manual of basic methods. John Wiley and Sons, Chichester

Kayes, R. (1987). Britain tests the water for marine conservation. New Scientist 114: 48-52

Koslow, J. A., Hanley, F., Wicklund, R. (1988). Effects of fishing on reef fish communities at Pedro Bank and Port Royal Cays, Jamaica. Mar. Ecol. Prog. Ser. 43: 201-212

Nikolsky, G. V (1965). Theory of fish population dynamics as the biological background for rational exploitation and management of fishery resources. Oliver \& Boyd, Edinburgh

Pimm, S. L. (1984). The complexity and stability of ecosystems Nature, Lond $307: 321-326$

Ricker, W. E. (1975). Computation and interpretation of biological statistics of fish populations. Bull. Fish. Res. Bd Can. 191. 1-379

Russ, G. R., Alcala, A. C. (1989). Effects of intense fishing pressure on an assemblage of coral reef fishes. Mar Ecol. Prog. Ser. 56: 13-27

Rothschild, B. J. (1967). Competition for gear in a multiple species fishery. J. Cons. int. Explor. Mer 31: 102-110

Van der Elst, R. P. (1981). A guide to the common sea fishes of southern Africa. Struik, Cape Town

Van der Elst, R. P. (1989) Marine recreational angling in South Africa. In: Payne, A.I.L., Crawford, R. J. M. (eds.) Oceans of life off southern Africa. Vlaeberg Publishers, Cape Town, p. 164-176

Weatherly, A. H. (1972). Growth and ecology of fish populations. Academic Press, London

Manuscript first received: March 22, 1991

Revised version accepted: June 19, 1991 